\title{
Prevalence of race 18 of Xanthomonas citri subsp. malvacearum on cotton in Brazil
}

\author{
Waleska de Sousa Braga ${ }^{1}$ - Rayssa Wadja Silveira da Cunha ${ }^{1} \cdot$ Nelson Dias Suassuna $^{1}$. \\ Wirton Macedo Coutinho ${ }^{1}$ (i)
}

Received: 6 October 2015 / Accepted: 8 February 2016 /Published online: 22 February 2016

(C) Sociedade Brasileira de Fitopatologia 2016

\begin{abstract}
Cotton bacterial blight caused by Xanthomonas citri subsp. malvacearum $(X \mathrm{~cm})$ is one of the most widely distributed and devastating diseases of cotton (Gossypium spp.) worldwide. Twelve $X c m$ races have been described in the world, with their relative prevalence varying by country. This study aimed to determine the current frequency and distribution of Xcm races in Brazil. Leaves showing cotton blight symptoms were collected from 12 cotton producing areas in the states of Bahia, Goiás, Mato Grosso and Mato Grosso do Sul. A total of 92 isolates were collected from surveyed areas. Race identification was performed by injection of bacterial suspensions into 10 differential cotton cultivars (Acala 44, Stoneville 2B-S9, Stoneville 20, Mebane B1, 1-10B, 101102B, Gregg 8, Empire B4, PDX P4 and S-295). All Xcm isolates were characterized as race 18 , indicating this to be the prevalent race in Brazil.
\end{abstract}

Keywords Gossypium hirsutum · Bacteria · Differential cultivars

Cotton blight disease caused by Xanthomonas citri subsp. malvacearum (ex Smith) Schaad et al. $(X \mathrm{Cm})$ is one of the most widely distributed and devastating diseases of cotton (Gossypium spp.) worldwide. Lint yield losses can range from 5 to $35 \%$ in susceptible varieties (Delannoy et al. 2005).

Twelve $X c m$ races have been described worldwide, with their relative prevalence varying by country. Among the

Section Editor: Bernardo Halfeld-Vieira

Wirton Macedo Coutinho

wirton.coutinho@embrapa.br

1 Embrapa Algodão, Campina Grande, PB, Brazil
$\mathrm{Xcm}$ races, race 18 is one of the most aggressive and occurs in almost all cotton producing areas (Hillocks 1992). However, highly virulent strains (HVSs) of Xcm that are more aggressive than race 18 have been identified in Africa (Follin 1983).

The most effective control method for cotton bacterial blight is the use of resistant cultivars. At least 22 resistance genes or gene combinations have been reported in cotton genotypes. These genes confer differing degrees of resistance to $X \mathrm{~cm}$ races that carry different avirulence genes (avr), in a typical gene-for-gene relationship (Delannoy et al. 2005). They have quantitative effects and may confer complete or partial resistance to specific races of the pathogen. Gene combinations $\mathrm{B}_{2} \mathrm{~B}_{3}$ and $\mathrm{B}_{9 \mathrm{~L}} \mathrm{~B}_{10 \mathrm{~L}}$ have been shown to confer resistance up to race 19 (Innes 1965; Innes et al. 1974), while $B_{12}$ confers resistance to all races, including the highly virulent race 20 from Africa, which overcomes the $\mathrm{B}_{2} \mathrm{~B}_{3}$ combination (Girardot et al. 1986; Wallace and El-Zik 1989).

The knowledge of the frequency and distribution of $X \mathrm{~cm}$ races in Brazil can contribute to the development of an efficient cotton breeding program and can help to predict resistance durability, promoting resistance against the pathogen by incorporating new resistant sources into newly developed varieties. Despite the recent finding that the Brazilian population of $\mathrm{Xcm}$ has a low phenotypic and genotypic variability (Oliveira et al. 2011), the latest race studies were carried out 34 years ago (Cia et al. 1973; Ruano and Mohan 1982). Meanwhile, the cotton-producing region migrated from the Northeast, South and Southeast regions to Central Brazil, more specifically in the Brazilian savanna ("cerrado"). Nowadays, about one million hectars are annually grown with cotton, approximately $95 \%$ of which is located in the cerrado region (Conab 2013). Therefore, the present study was undertaken to investigate the current distribution and frequency of $\mathrm{Xcm}$ races in the major cotton-producing areas of Brazil. 
Fig. 1 Counties from which cotton leaves with bacterial blight symptoms were collected

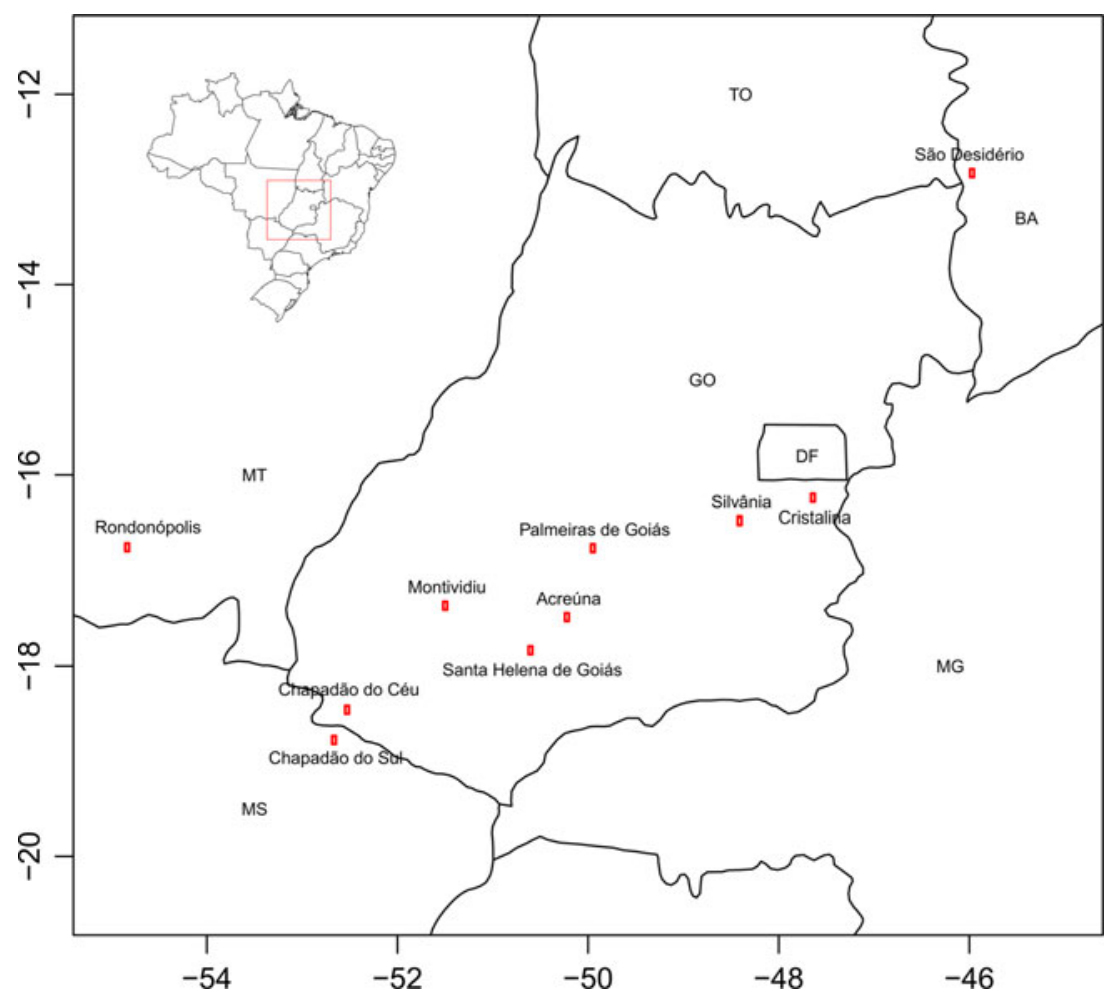

Leaves showing cotton blight symptoms were collected from 12 cotton producing areas in different counties in the states of Bahia, Goiás, Mato Grosso and Mato Grosso do Sul (Fig. 1). Approximately 10 leaves were collected from each location. Sample locations were geo-referenced, and the genotypes were identified (DP 90-Bt, FM 977, BRS Cedro, DP Acala 90, BRS Araça and ITA 90). Each leaf provided four independent isolates of $X \mathrm{~cm}$.

A total of $92 \mathrm{Xcm}$ isolates were collected. They were isolated from single leaf lesions in 523 medium (1\% sucrose, $0.4 \%$ yeast extract, $0.8 \%$ hydrolyzed acid casein, $0.2 \%$ $\mathrm{K}_{2} \mathrm{HPO}_{4}, 0.03 \% \mathrm{MgSO}_{4}$ ) solidified with $2 \%$ agar. The identities of the $\mathrm{Xcm}$ isolates were confirmed by negative Gram staining and biochemical tests (oxidase negative, catalase and amylase positive), as well as by pathogenicity tests on cotton cultivar Acala 44 (susceptible to all $\mathrm{Xcm}$ races).

Race identification was performed according to the system developed by Hunter et al. (1968). Plants of ten cotton differential cultivars (Acala 44, Stoneville 2B-S9, Stoneville 20, Mebane B1, 1-10B, 101-102B, Gregg 8, Empire B4, PDX P4 and S-295) were grown in pots containing a 3:1 (v/v) mixture of turf and vermiculite, and were inoculated with each $X \mathrm{~cm}$ isolate. Each isolate was grown at $30^{\circ} \mathrm{C}$ on 523 medium. After approximately $48 \mathrm{~h}$ of growth, the cultures were washed with a sterile saline solution $(0.85 \% \mathrm{NaCl})$, and the bacterial suspension was adjusted to $10^{8} \mathrm{cfu} / \mathrm{ml}$. Using a needle-less syringe, approximately $0.5 \mathrm{ml}$ of the freshly prepared bacterial suspension was gently injected into three sites on the abaxial side of two leaves of plants with 6 to 8 fully expanded leaves. Inoculated plants were maintained in a greenhouse at 25 $30{ }^{\circ} \mathrm{C}$ and $80 \%$ relative humidity, and the symptoms were scored 5 days after inoculation.

All $92 \mathrm{Xcm}$ isolates obtained from leaves with bacterial blight symptoms were characterized as race 18. All isolates induced a hypersensitive reaction 2 days after inoculation in varieties 101-102B and S-295, and a susceptibility reaction was observed 5 days after inoculation in varieties Acala 44, Stoneville 2BS9, Stoneville 20, Mebane B1, 1-10B, Gregg, Empire B4 and DPxP4 (Fig. 2).

Although race 18 is one of the most frequent and aggressive races, other less virulent races frequently coexist with
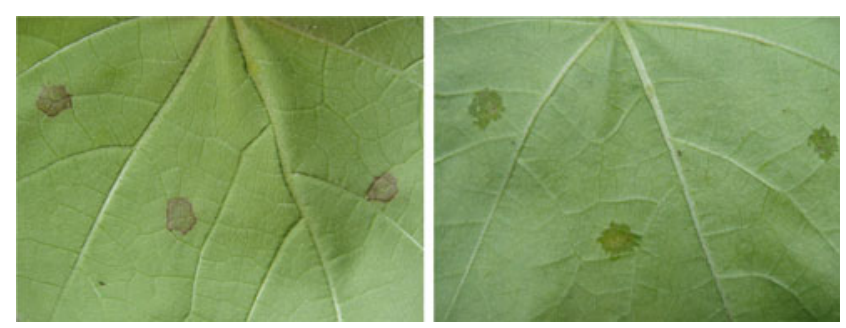

Fig. 2 Cotton varieties S-295 (left) and 1-10B (right) displaying hypersensitivity and susceptibility reactions, respectively, after inoculation with Xanthomonas citri subsp. malvacearum 
race 18 in cotton producing areas worldwide (Hussain 1984; Alippi and Hayward 1987; Allen and West 1991; Akello and Hillocks 2002; Gholve et al. 2005; Madani et al. 2010). Four less aggressive $\mathrm{Xcm}$ races $(3,8,10$ and 19) were identified in Brazil in the 1970's and 1980's in São Paulo and Paraná states (Cia et al. 1973; Ruano and Mohan 1982). These races were not detected in this work, most likely because the genetic background of the varieties currently cultivated in the surveyed area (Bahia, Goiás, Mato Grosso and Mato Grosso do Sul states) is quite different from those previously cultivated in São Paulo and Paraná states in the past. The modern varieties, possessing different combinations of resistance genes against $X \mathrm{~cm}$, may not promote the development of less aggressive races such as race 3 (virulent only to genes $B_{s m}$ and $B_{1 n}$ ), race 8 (virulent only to genes $B_{s m}, B_{2}, B_{7}$ and $B_{1 n}$ ), race 10 (virulent only to genes $\mathrm{B}_{\mathrm{sm}}, \mathrm{B}_{2}, \mathrm{~B}_{7}, \mathrm{~B}_{1 \mathrm{n}}$ and $\mathrm{B}_{\mathrm{N}}$ ) and race 19 (virulent only to genes $B_{1 n}$ and $B_{N}$ ). This is in agreement with the distribution of races in other countries, where authors report that virulent races are reduced when susceptible varieties are absent (Schnathorst et al. 1960; Chew et al. 1969; Brinkerhoff 1970). Race 18 is more aggressive than races 3, 8,10 and 19 , overcoming most resistance genes against bacterial blight except the combinations $\mathrm{B}_{2} \mathrm{~B}_{3} \mathrm{~B}_{\mathrm{sm}}$ (Follin et al. 1998; Innes et al. 1974), $B_{2} B_{3} B_{6}$ (Innes 1974), $B_{9 L} B_{10 L}$ (Innes 1965), and $B_{12}$ (Wallace and El-Zik 1989; Xiao et al. 2010).

In the last 20 years in Brazil, cotton breeding programs have developed resistance to several cotton diseases, including cotton bacterial blight, due to the transition of cotton producing areas from the Northeast, South and Southeast to the cerrado region and the subsequent increase in damage caused by several diseases. Breeders have used parental genotypes that carry the gene combinations $\mathrm{B}_{2} \mathrm{~B}_{3} \mathrm{~B}_{6}$ and $\mathrm{B}_{9 \mathrm{~L}} \mathrm{~B}_{10 \mathrm{~L}}$ (Lima and Vieira 1999), which are effective against most $X c m$ races worldwide, including race 18 . Currently, most cotton fields in Brazil are cultivated with transgenic varieties FM 975 WS, FM 980 GLT, TMG 81 WS, BRS 368 RF and TMG $43 \mathrm{WS}$ or non-transgenic variaties BRS 336, FM 910 and FM 993, all carrying those resistance gene combinations and which therefore are resistant to bacterial blight. The success on developing bacterial blight-resistant cotton cultivars has prevented epidemics or significant damage caused by $\mathrm{Xcm}$ in the country. However, the widespread deployment of cultivars possessing different combinations of resistance genes favors the establishment of race 18 over races $3,8,10$ and 19 .

Until the $1980 \mathrm{~s}$, the resistance gene combination $\mathrm{B}_{2} \mathrm{~B}_{3}$ was effective against all races of $X \mathrm{~cm}$, including race 18. However, highly virulent strains of $X \mathrm{~cm}$ identified in Africa, collectively designated as race 20 , overcome the resistance of the $\mathrm{B}_{2} \mathrm{~B}_{3}$ combination (Follin 1983).

The prevalence of race 18 in Brazil is indicative of the durability of the $\mathrm{B}_{2} \mathrm{~B}_{3}$ combination. Although the highly virulent strains of $\mathrm{Xcm}$ capable of overcoming resistance based on the $\mathrm{B}_{2} \mathrm{~B}_{3}$ combination were reported more than 30 years ago, none of the isolates tested in our study were capable of overcoming resistance in 101-102B $\left(\mathrm{B}_{2} \mathrm{~B}_{3} \mathrm{~B}_{\mathrm{sm}}\right)$ and $\mathrm{S}-295$ $\left(B_{12}\right)$. Nevertheless, preventive efforts should be made to develop germplasm resistant to race 20 of $X \mathrm{~cm}$. The cultivar S-295 carrying the gene $B_{12}$, which confers resistance to race 20 (Girardot et al. 1986; Wallace and El-Zik 1989), should be used as a parental strain for breeding new resistant varieties of cotton.

\section{References}

Akello B, Hillocks R (2002) Distribution and races of Xanthomonas axonopodis pv. malvacearum on cotton (Gossypium hirsutum) in Uganda. J Phytopathol 150:65-69

Alippi A, Hayward A (1987) Races of Xanthomonas campestris pv. malvacearum occurring in Queensland and Western Australia. Australas Plant Pathol 16:16

Allen S, West K (1991) Predominance of race 18 of Xanthomonas campestris pv. malvacearum on cotton in Australia. Plant Dis 75: 43-44

Brinkerhoff L (1970) Variation in Xanthomonas malvacearum and its relation to control. Annu Rev Phytopathol 8:85-110

Chew C, Presley J, Staten G (1969) Survey, screening, and breeding for bacterial blight resistance in cotton. Plant Dis Rep 53:391

Cia E, Balmer E, Ferraz AMC, Gridi-Papp IL, Paradela-Filho O (1973) Variabilidade de Xanthomonas malvacearum (E.F. Smith) Dowson, no estado de São Paulo. Anais Esc Super Agric Luiz de Queiroz 30: $457-463$

Conab (2013) Séries históricas. Available at: www.conab.gov.br/ conteudos.php? $\mathrm{a}=1252 \& \mathrm{t}=$. Accessed 28 Aug 2015

Delannoy E, Lyon B, Marmey P, Jalloul A, Daniel JF, Montillet JL, Essenberg M, Nicole M (2005) Resistance of cotton towards Xanthomonas campestris pv. malvacearum. Annu Rev Phytopathol 43:63-82

Follin J (1983) Races de Xanthomonas campestris pv. malvacearum (Smith) Dye en Afrique de l'Ouest et en Afrique Centrale. Coton Fibres Trop 38:274-279

Follin J, Girardot B, Mangano V, Benitez R (1998) New results on inheritance of immunity to bacterial blight (Xanthomonas campestris pv. malvacearum (Smith) Dye), race 18 and 20, in the cotton plant (Gossypium hirsutum L.). Coton Fibres Trop 43:172-174

Gholve V, Kurundkar B, Meshram M, Wasule D (2005) Prevalence of races of Xanthomnas axonopodis pv malvacearum in Marathwada region of Maharashtra State. J Cotton Res Dev 19:254-256

Girardot B, Hequet E, Yehouessi M, Guibordeau P (1986) Finding a variety of Gossypium hirsutum resistant to strains of Xanthomonas campestris pv. malvacearum (Smith) Dye virulent on association of major genes $\left(\mathrm{B}_{2}-\mathrm{B}_{3}\right.$ or $\left.\mathrm{B}_{9 \mathrm{~L}}-\mathrm{B}_{10 \mathrm{~L}}\right)$. Coton Fibres Trop 41:68-69

Hillocks R (1992) Bacterial blight. In: Hillocks R (ed) Cotton diseases. CAB International, Wallingford, pp 39-85

Hunter R, Brinkerhoff L, Bird L (1968) The development of a set of upland cotton lines for differentiating races of Xanthomonas malvacearum. Phytopathology 58:830-832

Hussain T (1984) Prevalence and distribuition of Xanthomonas campestris pv. malvacearum races in Pakistan and their reaction to different cotton lines. Trop Pest Manag 30:159-162

Innes N (1965) Inheritance of resistance to bacterial blight of cotton I. Allen (Gossypium hirsutum) derivatives. J Agric Sci 64:257-271

Innes N (1974) Resistance to bacterial blight in cotton varieties homozygous for combination of B resistance genes. Ann Appl Biol 78:8998 
Innes N, Brown S, Walker J (1974) Genetic and environmental variation for resistance to bacterial blight in upland cotton. Heredity 32:53-72

Lima E, Vieira R (1999) Melhoramento do algodoeiro para resistência às doenças. In: Beltrão N (ed) O Agronegócio do Algodão no Brasil, 2nd edn. Embrapa, Brasília, pp 296-314

Madani A, Marefat A, Behboudi K, Ghasemi A (2010) Phenotypic and genetic characteristics of Xanthomonas citri subsp. malvacearum, causal agent of cotton blight, and identification of races in Iran. Australas Plant Pathol 39:440-445

Oliveira JC, Albuquerque GMR, Xavier AS, Mariano RLR, Suassuna ND, Souza EB (2011) Characterization of Xanthomonas citri subsp. malvacearum causing cotton angular leaf spot in Brazil. J Plant Pathol 93:707-712
Ruano O, Mohan S (1982) Nova raça de Xanthomonas campestris pv. malvacearum (Smith) Dye no estado do Paraná. Fitopatol Bras 7: 439-442

Schnathorst W, Halisky P, Martin R (1960) History, distribution, races and disease cycle of Xanthomonas malvacearum in California. Plant Dis Rep 44:603-608

Wallace T, El-Zik K (1989) Inheritance of resistance in three cotton cultivars to the HV1 isolate of bacterial blight. Crop Sci 29:1114-1119

Xiao J, Fang DD, Bhatti M, Hendrix B, Cantrell R (2010) A SNP haplotype associated with a gene resistant to Xanthomonas axonopodis pv. malvacearum in upland cotton (Gossypium hirsutum L.). Mol Breed 25:593-602 